\title{
HYGROSCOPICITY AND AMMONIA VOLATILIZATION LOSSES FROM NITROGEN SOURCES IN COATED UREA ${ }^{(1)}$
}

\author{
Letícia de Abreu Faria ${ }^{(2)}$, Carlos Antonio Costa do Nascimento ${ }^{(3)}$, Barbara Paquier \\ Ventura $^{(4)}$, Gabriela Perissinotto Florim ${ }^{(4)}$, Pedro Henrique de Cerqueira Luz ${ }^{(5)} \&$ \\ Godofredo Cesar Vitti ${ }^{(6)}$
}

\begin{abstract}
SUMMARY
Hygroscopic fertilizers tend to absorb moisture from the air and may have undesirable characteristics such as moistness, clumping and lower fluidity, hampering the application. The increasing use of urea is due to its numerous advantages, although this nitrogen $(\mathrm{N})$ source is highly susceptible to volatilization losses, particularly when applied to the soil surface of management systems with conservation of crop residues. The volatilization losses can be minimized by slow or controlled-release fertilizers, with controlled water solubility of the urea-coating materials; and by stabilized fertilizers, which prolong the period during which $\mathrm{N}$ remains in the amide or ammonia forms by urease inhibitors. This study evaluated the hygroscopicity of and ammonia volatilization from urea coated with boric acid and copper sulfate or with sulfur. The hygroscopicity of the sources was evaluated over time after exposure to five levels of relative humidity $(\mathrm{RH})$ and volatilization evaluated after application to the soil surface covered with sugarcane trash. Ammonium nitrate has a low potential for volatilization losses, but is highly hygroscopic. Although coating with boric acid and copper sulfate or elemental sulfur reduced the critical humidity level of urea, the delay in the volatilization process is a potential positive factor.
\end{abstract}

Index terms: boric acid, sulfur, crop residues, copper sulphate.

(1) Research FAPESP grantee. Received for publication on August 6, 2013 and approved on March 28, 2014.

(2) Post-Doctoral Researcher - Centro de Energia Nuclear na Agricultura - CENA/USP. Av. Centenário, 303. Postal Box 96. CEP 13400-970 Piracicaba (SP), Brazil. E-mail: evazoot@yahoo.com.br

(3) $\mathrm{PhD}$ Candidate in Soil Science and Plant Nutrition Graduate Program - Escola Superior de Agricultura Luiz de Queiroz ESALQ/USP. E-mail: cacnagro@yahoo.com.br

(4) Undergraduate in Agronomy, ESALQ/USP. E-mail: barbara.psquier@gmail.com, gabi_0941@hotmail.com

(5) Full Professor at Animal Science Department, FZEA/USP. Av. Duque de Caxias, 225. CEP 13635-900 Pirassununga (SP), Brazil. E-mail: phcerluz@usp.br

(6) Full Professor at Soil Science Department, ESALQ/USP. E-mail: gcvitti@usp.br 


\title{
RESUMO: HIGROSCOPICIDADE E PERDAS DE DIFERENTES FONTES DE NITROGÊNIO POR VOLATILIZAÇÃO DE AMÔNIA EM UREIA REVESTIDA
}

\begin{abstract}
Fertilizantes higroscópicos tendem a absorver a umidade do ar e podem apresentar características indesejáveis como mela, empedramento, menor fluidez, em que a consequência é a difícil aplicação. O crescente uso de ureia é atribuido às suas inúmeras vantagens, porém essa fonte apresenta elevada susceptibilidade a perdas por volatilização de amônia, principalmente quando aplicada em superficie em sistemas com conservação da palhada. Para minimizar esse tipo de perda, existem os fertilizantes de liberação lenta ou controlada pelo controle de solubilidade em água de materiais utilizados no revestimento da ureia; e os estabilizados, que prolongam o tempo em que o $N$ permanece nas formas amídica ou amoniacal por meio de inibidores de urease. Objetivou-se, neste trabalho, avaliar a higroscopicidade e as perdas por volatilização de amônia da ureia revestida com ácido bórico e sulfato de cobre e ureia revestida com enxofre. A higroscopicidade das fontes foi avaliada ao longo do tempo, após a exposição a cinco níveis de umidade relativa do ar; e a volatilização avaliada, após aplicação em superfície na palhada da cana. O nitrato de amônio apresentou baixo potencial de perdas por volatilização, porém teve elevada higroscopicidade. O revestimento com acido bórico e sulfato de cobre ou com enxofre elementar reduziu o ponto de umidade crítico da ureia, porém apresentou como um dos fatores positivos o potencial em retardar o processo de volatilização.
\end{abstract}

Termos de indexação: ácido bórico, enxofre, palhada, sulfato de cobre.

\section{INTRODUCTION}

The application of nitrogen $(\mathrm{N})$ fertilizer, sidedressed or broadcast, is rather common in tropical farming systems in view of the logistical benefits. The applied fertilizers can be exposed to humidity, abrasion, high temperatures, and other factors, affecting the physical and chemical integrity and thus reducing the quality of application and use efficiency; the physical quality of fertilizers is therefore fundamental.

The quality of mineral fertilizers can be classified by chemical, physical and physico-chemical properties. The physical characteristics are subdivided into particle size, consistency and fluidity, which define the quality of fertilizer distribution at application and are rather difficult to control by official legislation (Alcarde et al., 1989).

Fertilizers in solid form are the most commonly used in Brazil, and one of the essential physicochemical characteristics of this type of fertilizer is hygroscopicity (Sauchelli, 1960). This parameter indicates the maximum relative humidity to which each substance or mixture of substances can be exposed without reaching a level of water absorption that would be critical for the fertilizer use efficiency (Alcarde et al., 1989).

Studies on the possibility of increasing fertilizer efficiency have been intensified, mainly in view of the increasing food demand and the intrinsic need for sustainable production in terms of socio-economicenvironmental aspects.

In Brazil, concerns about $\mathrm{N}$ fertilizer have increased, mainly as a result of the expansion of the no-tillage and minimum tillage systems. Despite the numerous advantages of these managements, the practice of leaving sugarcane trash on the soil surface reduces the efficiency of $\mathrm{N}$ fertilizer when the source is urea, as a result of volatilization losses.

The intensive use of urea as $\mathrm{N}$ fertilizer is attributed to advantages such as high $\mathrm{N}$ concentration; low costs of production, transportation, storage and distribution; ease of application; high water solubility, and low corrosivity (Lara Cabezas et al., 1997; Kiss \& Simihãian, 2002). The disadvantage of using this source is the high susceptibility to volatilization losses, particularly when applied to the surface in systems where crop residues are left on the soil surface, resulting in a low fertilizer use efficiency of the agricultural system.

Ammonium nitrate has a high agronomic value for containing a nitric and also an ammonia radical, reducing the potential of volatilization and soil acidification compared to other $\mathrm{N}$ sources (Franco \& Saraiva Neto, 2007). About $80 \%$ of the global ammonium nitrate production is concentrated in Europe, the United States and the former Soviet Union. These regions account for $72 \%$ of the consumption of the product. In Brazil, transport and marketing are restricted, limiting its use, due to its potential use to manufacture explosives (Cantarella et al., 2008).

When urea is surface-applied, N losses by volatilization vary from 16 to $78 \%$, (Kiss \& Simihãian, 2002; Cantarella, 2007). According to Trenkel (2010), these losses can be minimized by slow or controlledrelease fertilizers which reduce the hydrolysis rate by controlling the water solubility of materials used in the coating of urea and; by stabilized fertilizer, 
which extend the period of persistence of $\mathrm{N}$ in amide or ammonia forms by urease inhibitors. Processes of granulation, granule coating and storage conditions influence the hygroscopicity of fertilizers.

The hypotheses of this study were that urea coating affects the fertilizer hygroscopicity and that the coating materials $\mathrm{B}$ and $\mathrm{Cu}$ or $\mathrm{S}$ reduce volatilization losses. To generate useful information for the production, storage and management of $\mathrm{N}$ fertilizers with a view to an efficient use, we evaluated the hygroscopicity and $\mathrm{NH}_{3}$ volatilization losses from urea-coated fertilizer in comparison with conventional urea and nitrate ammonium.

\section{MATERIAL AND METHODS}

The studies were conducted in a laboratory and greenhouse of the Faculty of Agriculture "Luiz de Queiroz" (ESALQ) of the University of São Paulo (USP) in Piracicaba, São Paulo.

We evaluated urea-based $\mathrm{N}$ fertilizers treated with coating technologies, i.e., coating with boric acid and copper sulfate - UCuB ( $=44.6 \%, \mathrm{~B}=0.39 \%$ and $\mathrm{Cu}=0.16 \%)$ and elemental sulfur-coated urea - US $(\mathrm{N}=40.1 \%, \mathrm{~S}=16 \%)$ compared to conventional urea - $\mathrm{u}(\mathrm{N}=44.81 \%)$ and ammonium nitrate $(\mathrm{N}=33 \%)$. The evaluated materials consisted of fertilizers currently available on the market with added values by technological approaches to expand the use efficiency by reducing the potential losses.

The hygroscopicity of fertilizers was measured in the laboratory and volatilization losses were observed under greenhouse conditions. The hygroscopicity was determined by a method proposed by Alcarde et al. (1992), in which fertilizers are exposed to environments with increasing relative air humidity (RAH) and evaluated after 3, 6, 12, 24, and $48 \mathrm{~h}$, with three replications.

The environments with different RAH consisted of $250 \mathrm{~mm}$ diameter desiccators containing sulfuric acid solutions of $7.6 ; 6.1 ; 4.6 ; 3.2$; or $2.8 \mathrm{~mol} \mathrm{~L}^{-1}$ respectively, to reach humidity levels of $38,55,76$, 86 , and $92 \%$. The sulfuric solutions inserted at the base of the desiccator were applied $24 \mathrm{~h}$ before beginning fertilizer exposure to stabilize the RAH, which was measured with a hygrometer fixed within the desiccator.

Samples containing approximately $10 \mathrm{~g}$ fertilizer were placed in containers of known weight, exposed to the RAH environments at an average temperature of $20^{\circ} \mathrm{C}$, and weighed periodically.

The percentage of absorbed water $(\% \mathrm{H})$ was calculated in relation to the dry sample weight by the expression $\mathrm{H}=[(\mathrm{hM}-\mathrm{dM}) / \mathrm{dM}] \times 100$, where $\mathrm{hM}=$ weight of wet sample after exposure, in $\mathrm{g}$, and $\mathrm{dM}=$ weight of the initial dry sample, in $\mathrm{g}$.
The $\mathrm{NH}_{3}$ losses by volatilization were assessed in a randomized block design with four replications. The experimental units consisted of pots with an exposed surface area of $0.022 \mathrm{~m}^{2}$ (diameter $17 \mathrm{~cm}$ ), containing $2.0 \mathrm{~kg}$ of air-dried soil, wrapped in plastic bags to prevent water runoff and prevent $\mathrm{N}$ loss by leaching.

Samples of soil and trash were collected in an area of sugarcane ratoon after mechanical harvesting without burning. The soil was collected from the surface layer $(0-0.20 \mathrm{~m})$ of a Latossolo VermelhoAmarelo profile (Santos et al., 2006). The data of the soil chemical (Raij et al., 2001), sulfur (Vitti, 1989) and physical properties (Camargo et al., 1986) and of fertility are shown in table 1.

The contents of $\mathrm{N}, \mathrm{P}, \mathrm{K}, \mathrm{Ca}, \mathrm{Mg}$ and $\mathrm{S}$ were estimated in an amount of $7.7 \mathrm{t} \mathrm{ha}^{-1}$ of sugarcane trash on the soil surface $\left(65^{\circ} \mathrm{C}\right)$ and were, respectively, $42,8,22,60,11$ and $6 \mathrm{~kg} \mathrm{t}^{-1}$ and the $\mathrm{C} / \mathrm{N}$ ratio was determined as described by Malavolta et al. (1997) at $95 / 1$. To the surface area of all pots $19 \mathrm{~g}$ of trash were applied.

Nitrogen fertilizers were applied to the surface at rates of $120 \mathrm{~kg} \mathrm{ha}^{-1}$ without incorporation, as recommended for ratoon crops $\left(1.3 \mathrm{~kg} \mathrm{t}^{-1} \mathrm{~N}\right.$ of stalk production) (Vitti et al., 2013).

The experimental units were arranged on the floor of the greenhouse to prevent that the uptake of volatilized ammonia would be hampered by the wind from the fans. The experimental units were weighed daily and irrigated periodically to maintain soil moisture at $50 \%$ field capacity.

Gaseous losses by ammonia volatilization to the atmosphere were evaluated without using plants because the $\mathrm{N}$ assimilated by plants could be lost as ammonia by the shoots as reported by Trivelin et al. (2002), leading to an overestimation of the $\mathrm{N}$ losses from the applied fertilizer.

The volatilized ammonia was captured by foams $\left(18.0 \times 18.0 \mathrm{~cm}\right.$, density $\left.0.02 \mathrm{~kg} \mathrm{dm}^{-3}\right)$ soaked in $100 \mathrm{~mL}$ of $0.5 \mathrm{~mol} \mathrm{~L}^{-1}$ phosphoric acid solution containing $50 \mathrm{~mol} \mathrm{~L}^{-1}$ glycerin coupled to PVC plates $(20.0 \times 20.0 \times 0.2 \mathrm{~cm}$ width, length and thickness, respectively), and surrounded by polytetrafluoroethylene (PTFE) tape that is ammonium permeable and water impermeable, according to the method described by Alves et al. (2007).

One foam per pot was installed at a height of $1.0 \mathrm{~cm}$, mounted on wooden shafts, with the PVC plate facing upwards to prevent the air above the ammonia collector from being captured and masking the data. Ammonia volatilization was assessed until 20 days after fertilizer application (Cantarella et al., 2008; Alves et al., 2011; Faria et al., 2013; Nascimento et al., 2013). The foams were replaced 2, 4, 6, 913 , and 17 days after fertilization and stored in plastic bags at $-4^{\circ} \mathrm{C}$ for later extraction and analysis (Alves et al., 2007). 
Table 1. Chemical properties of the soil used in the volatilization experiment

\begin{tabular}{|c|c|c|c|c|c|c|c|c|c|c|c|c|c|c|}
\hline $\mathrm{pH}\left(\mathrm{CaCl}_{2}\right)$ & SOM & $\mathbf{P}$ & $\mathrm{S}$ & $\mathbf{K}$ & $\mathbf{C a}$ & Mg & $\mathrm{Al}^{3+}$ & $\mathrm{H}+\mathrm{Al}$ & CTC & V & $\mathbf{m}$ & Sand & Silt & Clay \\
\hline & $\mathrm{g} \mathrm{dm}^{-3}$ & $\mathrm{mg} \mathrm{dm}{ }^{-3}$ & & 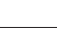 & 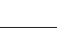 & $\mathrm{mmo}$ & $m^{-3}$ & & - & - & 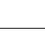 & 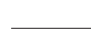 & $\mathrm{g} \mathrm{kg}^{-}$ & 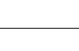 \\
\hline 4.9 & 15 & 6 & 9 & 0.8 & 10 & 5 & 5 & 30 & 47.4 & 34 & 16 & 850 & 25 & 125 \\
\hline
\end{tabular}

The amount of $\mathrm{NH}_{3}$ volatilized from the soil was assessed simultaneously in a control (without $\mathrm{N}$ ) under the same experimental conditions to generate data underlying the calculations of $\mathrm{NH}_{3}$ volatilized from fertilizer.

The $\mathrm{NH}_{3}$ contained in the foams was extracted by washing them in $300 \mathrm{~mL}$ of water on a Büchner funnel with a porous plate connected to a vacuum pump. As described by Su et al. (1998) and Kamogawa \& Teixeira (2009), an aliquot of $50 \mathrm{~mL}$ was withdrawn from the final solution of the washing of each foam, for distillation and quantification of volatilized $\mathrm{NH}_{3}$ by flow injection analysis.

From the data of the total volatilized N (tVN) resulting from the $\mathrm{N}$ loss from the soil and the fertilizer, the results of $\mathrm{N}$ volatilized from fertilizer $(\mathrm{NVf})$ was obtained by the equation: $\mathrm{NVf}=\mathrm{tVN}-\mathrm{NVc}$, where $\mathrm{NV}$ c indicates the volatilized $\mathrm{NH}_{3}$ in the control treatment. The data were analyzed by the statistical program SAS (2004). The sources were compared with the analysis of comparison of means by the Tukey test $(p<0.005)$ and regression analysis for the evaluation of hygroscopicity over time.

\section{RESULTS}

Increase in RAH caused an increase in water absorption of the fertilizers, and this effect was increased over time (Table 2).

From the RAH level of $55 \%$ upwards, the moisture absorption in the treatments with coated urea increased linearly with exposure time (Table 2), but differed from conventional urea with highest moisture accumulation after $48 \mathrm{~h}$ with RAH of $76 \%$ or more.

The superiority of ammonium nitrate over the other urea sources in terms of susceptibility to volatilization losses was statistically proven with a total loss of $0.2 \mathrm{~kg} \mathrm{ha}^{-1} \mathrm{NH}_{3}-\mathrm{N}$. The total amounts of $\mathrm{NH}_{3}$ lost by volatilization from urea-based fertilizers were $9.6,10.9$ and $13.3 \mathrm{~kg} \mathrm{ha}^{-1}$, respectively, for urea coated with $\mathrm{B}$ and $\mathrm{Cu}$, urea and sulfur-coated urea, which were relatively low according to Kiss \& Simihãian (2002) and Cantarella (2007), but did not differ, i.e., the evaluated technologies had no reducing effect on volatilization (Figure 1).

Among the urea-based fertilizers, the $\mathrm{NH}_{3}$ volatilization losses did not differ significantly from each other, but occurred at different times (Figure 2).

\section{DISCUSSION}

The hygroscopic nature of ammonium nitrate could be observed when exposed to RAH of $55 \%$ or more, although this level was below the critical humidity, according to Alcarde (1992), of 59.4\%. Considering that the critical humidity of urea is $75.2 \%$ (Alcarde, 1992), this $\mathrm{N}$ fertilizer had no significant effect on moisture absorption when exposed to the highest RAH levels evaluated (Table 2). Of the materials used for urea coating, the hygroscopicity of the mixture of boric acid and copper sulfate was highest (Table 2). The critical humidity of urea was decreased by the coatings, although at lower hygroscopicity degrees than of ammonium nitrate. Alcarde et al. (1989) and Alcarde (1992) concluded that water absorption by urea at levels below its critical humidity can be attributed to the presence of impurities in the fertilizer. These authors found that in substance mixtures, the critical humidity is lower than that of either component alone, i.e., hygroscopicity is greater. Although the coating is not considered an impurity, it consists of aggregated chemicals with distinct properties of fertilizers, which explains the results in which the coatings reduced the critical humidity of the urea fertilizer.

The exposure of fertilizers to high RAH can affect some of their physicochemical characteristics, hampering the application. Our results reinforce the importance of good storage conditions, as well as the reduction of the interval between fertilizer delivery to the field and fertilization at high RAH.

The application of amidic sources without incorporation under a thick trash layer on the surface of a sandy soil resulted in a high susceptibility to volatilization losses. The volatilization potential of soils is varied; two factors of influence on $\mathrm{NH}_{3}$ volatilization from urea are the clay and sand contents, since clay decreases $\mathrm{NH}_{3}$ volatilization significantly due to its ability to fix $\mathrm{NH}_{4}{ }^{+}$(Francisco et al., 2011; Nascimento et al., 2012). The $\mathrm{NH}_{3}$ losses from ammonium nitrate were practically zero, even when applied superficially on trash, corroborating results of Nascimento et al. (2013) and Faria et al. (2013). The direct supply of ammonium and nitrate forms, i.e., the absence of the passage of $\mathrm{N}$ to form ammonia under acidic soil conditions, explains the absence of volatilization losses from ammonium nitrate. 
Table 2. Absorbed moisture by the fertilizers after exposure to increasing relative air humidity (RAH) levels over exposure time

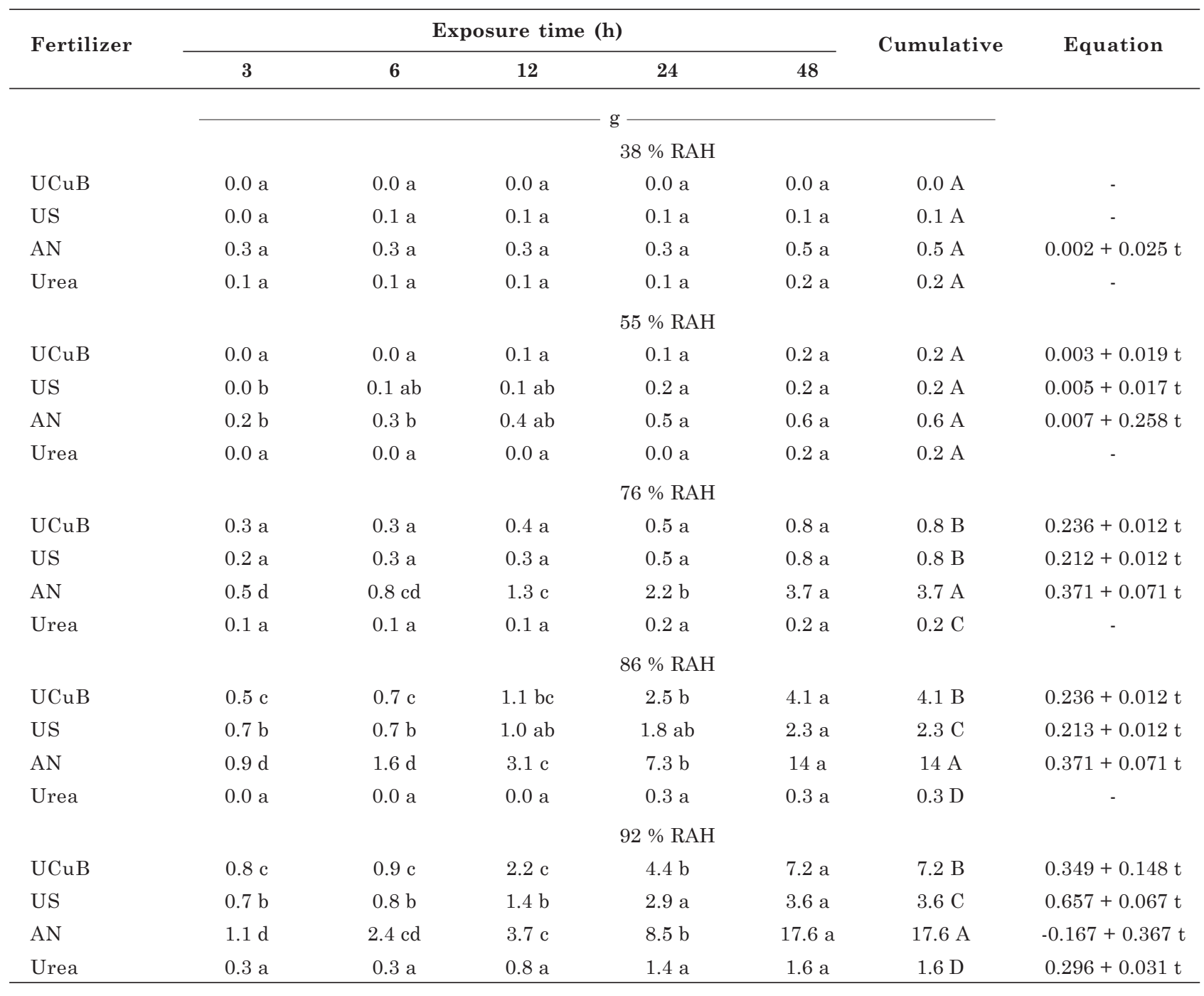

UCuB: urea coated with boric acid and copper sulfate; US: elemental sulfur-coated urea; AN: ammonium nitrate; t: exposure time. Means followed by the same uppercase letter in the column or lowercase letter in the row do not differ significantly by the Tukey test $(\mathrm{p}<0.05)$.

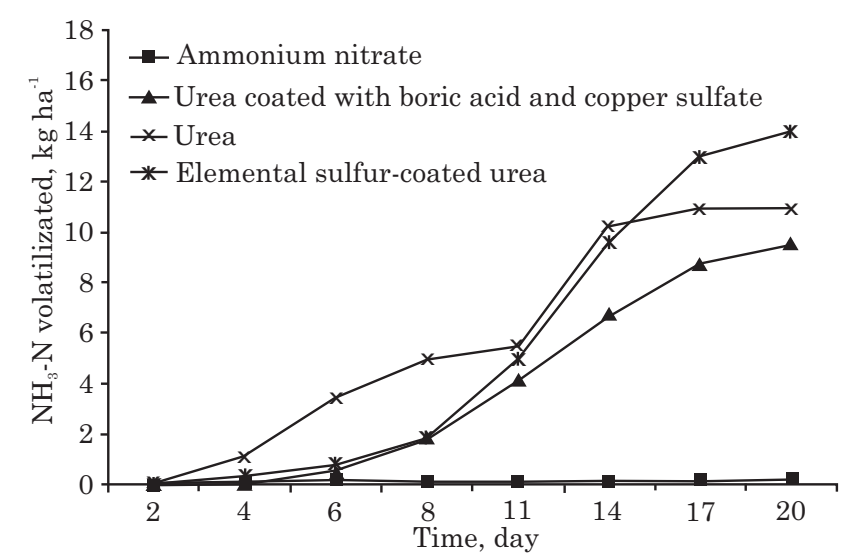

Figure 1. Cumulative volatilization losses of ammonia over time after fertilization.
The volatilization losses of $\mathrm{NH}_{3}$ from urea coated with boric acid and copper sulfate, urea, and elemental sulfur-coated urea were low (Figure 1). The magnitude of ammonia volatilization losses from urea was influenced by the temperature, moisture, concentration, and activity of the enzyme urease. Nascimento et al. (2013) and Faria et al. (2013) also reported low losses at low and high humidity, respectively.

The application of urea to the surface can reach high levels, as observed by Lara Cabezas \& Souza (2008), who reported losses of up to $77 \%$ of the total N applied.

In the first days after application of urea and ureabased coated fertilizers, ammonia losses were smaller (Figure 2), suggesting that the coatings can somewhat 


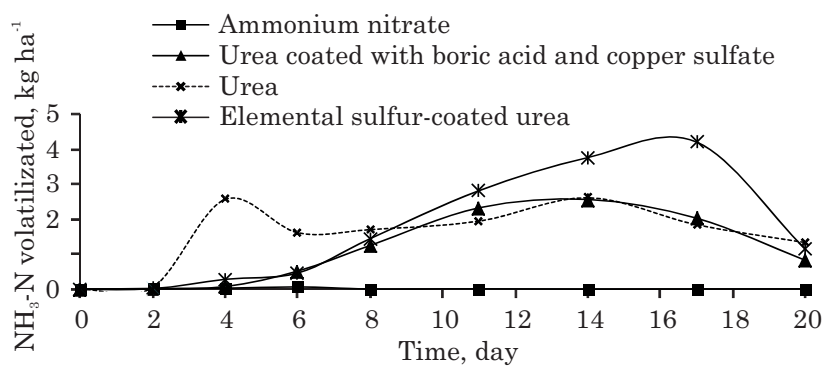

Figure 2. Ammonia volatilization losses over time after fertilization.

reduce volatilization losses or at least delay them until the $8^{\text {th }}$ day after fertilization.

The application of the second water level ( $12^{\text {th }}$ day after fertilization), with insufficient volume to incorporate the fertilizers into the soil induced higher volatilization losses in all urea treatments (Figure 2).

The increasing ammonia loss rates after water application can be explained by water evaporation (Lara Cabezas et al., 1997) and by the reduction of the protective effect of the coating material in both sources. In the case of sulfur-coated urea, the elemental sulfur cover was probably broken down, since the dissolution of urea in the soil solution is controlled by the hydrolytic and microbial degradation of the protective sulfur coating, as well as by the micropores and imperfections in it.

The reduction in efficiency of the inhibitors can be verified by higher losses over time. Copper is rapidly immobilized by the soil, and urea moves freely in soil water or by diffusion, so that urea is diffused beyond the influence zone of $\mathrm{Cu}$, making its action ineffective (Gaylord, 1961; Geissler et al., 1970).

Boric acid and copper sulfate or elemental sulfur as coating material, in spite of the higher hygroscopicity than of urea at high RAH, contributed to delay the volatilization process.

\section{CONCLUSIONS}

1. The coating of urea influences its hygroscopicity, making it more susceptible to levels of relative air humidity higher than $75 \%$.

2. Urea coating with $\mathrm{B}$ and $\mathrm{Cu}$ or with $\mathrm{S}$ did not affect the $\mathrm{NH}_{3}$ losses, but delayed the loss peaks.

\section{ACKNOWLEDGEMENT}

The authors gratefully acknowledge the financial support by the State of São Paulo Research Foundation (FAPESP).

\section{LITERATURE CITED}

ALCARDE, J.C. Corretivos da acidez dos solos: Características e interpretações técnicas. B. Técnico ANDA, 2:26, 1992.

ALCARDE, J.C.; GUIDOLIN, J.A. \& LOPES, A.S. Os adubos e a eficiência das adubações. B. Técnico ANDA, 3:35, 1989.

ALVES, A.C.; ALVES, T.C.; MACEDO, F.B.; BERNARDI, A.C.C.; OLIVEIRA, P.P.A. \& ROCHETTI, R.C. Adição de zeolita para redução da volatilização de $\mathrm{NH}_{3}$ em solo fertilizado com ureia. São Carlos, Embrapa, 2007. 4p. (Circular Técnica, 55)

ALVES, A.C.; OLIVEIRA, P.P.A.; HERLING, V.R.; TRIVELIN, P.C.O.; LUZ, P.H.C.; ALVES, T.C.; ROCHETTI, R.C. \& BARIONI JUNIOR, W. New methods to quantify $\mathrm{NH}_{3}$ volatilization from fertilized surface soil with urea. R. Bras. Ci. Solo, 35:133-140, 2011.

CAMARGO, O.A.; MONIZ, A.C. \& VALADARES, J.M. Métodos de análise química, mineralogia e física de solos. Campinas, Instituto Agronômico de Campinas, 1986. 94p. (Boletim Técnico, 78)

CANTARELLA, H. Nitrogênio. In: NOVAIS, R.F.; ALVAREZ V., V.H.; BARROS, N.F.; FONTES, R.L.F.; CANTARUTTI, R.B. \& NEVES, J.C.L., eds. Fertilidade do solo. Viçosa, MG, Sociedade Brasileira de Ciência do Solo, 2007. p.422-423.

CANTARELLA, H.; TRIVELIN, P.C.O.; CONTIN, T.L.M.; DIAS, F.L.F.; ROSSETTO, R.; MARCELINO, R.; COIMBRA, R.B. \& QUAGGIO, J.A. Ammonia volatilization from urease inhibitor-treated urea applied to sugarcane trash blankets. Sci. Agric., 65:397-401, 2008.

FARIA, L.A.; NASCIMENTO, C.A.C.; VITTI, G.C.; LUZ, P.H.C. \& GUEDES, E.M.S. Loss of ammonia from nitrogen fertilizers applied to maize and soybean straw. R. Bras. Ci. Solo, 37:969-975, 2013.

FRANCISCO, S.S.; URRITIA, O.; MARTIN, V.; PERISTEROPOULOS, A. \& GARCIA-MINA, J.M. Efficiency of urease and nitrification inhibitors in reducing ammonia volatilization from diverse nitrogen fertilizers applied to different soil types and wheat straw mulching. J. Sci. Food Agric., 91:1569-1575, 2011.

FRANCO, J.A.M. \& SARAIVA NETO, A. Produção de fertilizantes nitrogenados e suprimentos de matériaprima. In: YAMADA, T.; ABDALLA, S.R.S. \& VITTI, G.C., eds. Nitrogênio e enxofre na agricultura brasileira. Piracicaba, IPNI, 2007. p.73-107.

GAYLORD, M.V. Gaseous losses of ammonia from surfaceapplied nitrogenous fertilizers. J. Agric. Food Chem., 9:280-283, 1961.

GEISSLER, P.R.; SOR, K. \& ROSENBLATT, T.M. Urease inhibitors. U.S. Patent No. 3:518-523, 1970.

KAMOGAWA, M.Y. \& TEIXEIRA, M.A. Auto amostrador de baixo custo para análise por injeção em fluxo. Quím. Nova, 32:1644-1646, 2009. 
KISS, S. \& SIMIHÃIAN, M. Improving efficiency of urea fertilizers by inhibition of soil urease activity. Dordrecht, Kluwer Academic Publishers, 2002. 417p.

LARA CABEZAS, W.A.R. \& SOUZA, M.A.S. Volatilização de amônia, lixiviação de nitrogênio e produtividade de milho em resposta à aplicação de misturas de ureia com sulfato de amônio ou com gesso agrícola. R. Bras. Ci. Solo, 32:2331-2342, 2008.

LARA CABEZAS, W.A.R.; KORNDÖRFER, G.H. \& MOTTA, S.A. Volatilização de $\mathrm{N}-\mathrm{NH}_{3}$ na cultura de milho: I. Efeito da irrigação e substituição parcial da ureia por sulfato de amônio. R. Bras. Ci. Solo, 21:481-487, 1997.

MALAVOLTA, E.; VITTI, G.C. \& OLIVEIRA, S.A. Avaliação do estado nutricional de plantas. 2.ed. Piracicaba, Potafos, 1997. 319p.

NASCIMENTO, C.A.C.; FARIA, L.A.; VITTI, G.C.; ONO, E.L.K. \& ZAVASCHI, E. Fly ash as zeolites for reducing nitrogen losses by volatilization. Semina: Ci. Agron., 33:3023-3032, 2012.

NASCIMENTO, C.A.C.; VITTI, G.C.; FARIA, L.A.; LUZ, P.H.C. \& MENDES, F.L. Ammonia volatilization from coated urea forms. R. Bras. Ci. Solo, 37:1057-1063, 2013.

RAIJ, B. van; ANDRADE, J.C.; CANTARELLA, H. \& GUAGIO, J.A. Análise química para avaliação da fertilidade de solos tropicais. Campinas, Instituto Agronômico de Campinas, 2001. 285p.
SANTOS, H.G.; JACOMINE, P.K.T.; ANJOS, L.H.C.; OLIVEIRA, V.A.; OLIVEIRA, J.B.; COELHO, M.R.; LUMBRERAS, J.F. \& CUNHA, T.J.F. Sistema brasileiro de classificação de solos. 2.ed. Rio de Janeiro, Embrapa Solos, 2006. 306p.

SAS Institute Inc. SAS Online Doc ${ }^{\circledR}$ 9.1.3. Cary, 2004.

SAUCHELLI, V., ed. Chemistry and technology of fertilizers. New York, Reinhold, 1960. 692p.

SU, X.L.; CHEN, P.; QU, X.G.; WEI, W.Z \& YAO, S.Z. A novel flow-injection system for simultaneous determination of nitrate and nitrite based on the use of a zinc reductor and a bulk acoustic wave impedance detector. J. Microchem., 59:341-350, 1998.

TRENKEL, M.E. Slow and controlled-release and stabilized fertilizers: an option for enhancing nutrient use efficiency in agriculture. Paris, International Fertilizer Industry Association (IFA), 2010. 167p.

TRIVELIN, P.C.O.; OLIVEIRA, M.W.; VITTI, A.C.; GAVA, G.J.C. \& BENDASSOLLI, J.A. Perdas do nitrogênio da ureia no sistema solo-planta em dois ciclos de cana-deaçúcar. Pesq. Agropec Bras., 37:193-201, 2002.

VITTI, G.C. Avaliação e interpretação do enxofre no solo e na planta. Jaboticabal, FUNEP, 1989. 37p.

VITTI, G.C.; LUZ, P.H.C. \& ALTRAN, W.S. Nutrição e Adubação. In: BORÉM, A. \& SANTOS, F., eds. Cana-deAçúcar - Do plantio à colheita. Viçosa, MG, Universidade Federal de Viçosa, 2013. p.49-75. 